\title{
Monoclonal antibodies raised against membrane glycoproteins from mouse brain recognize $\mathrm{N}$-linked oligomannosidic glycans
}

\author{
Brigitte Schmitz ${ }^{1,3}$, Jasna Peter-Katalinic ${ }^{2}$, Heinz Egge $^{2}$ \\ and Melitta Schachner ${ }^{1}$ \\ 'Department of Neurobiology, Swiss Federal Institure of Technology, \\ Honggerberg, 8093 Zürich, Swizerland and 'Instiute of Physiological \\ Chemistry, Nußallee 11, University of Bonn, 5300 Bonn, FRG \\ ${ }^{3}$ Present address: Institute of Anatomy, Physiology and Hygiene of Domestic \\ Animals, University of Bonn, Katzenburgweg 7-9, 5300 Bonn, FRG
}

Monoclonal $\mathrm{L3}$ and $\mathrm{LA}$ antibodies have been shown to recognize carbohydrate epitopes on several neural cell adhesion molecules; these epitopes can be released by treatment with endoglycosidase $H$. In the present study, we have identified the oligosaccharides released by endoglycosidase $H$ from the cell adhesion molecules AMOG and L1 by fast-atom bombardment mass spectrometry as being solely of the oligomannosidic type. Using neoglycolipids of oligomannosidic glycans, we also report that both antibodies show the highest reactivity with the $\alpha$-manno-pentaose Man $\alpha 1-3-[\operatorname{Man} \alpha 1-6(\operatorname{Man} \alpha 1-3) \operatorname{Man} \alpha 1-6]-M a n$, but decreasing reactivity with the $\alpha$-manno-hexaose, heptaose, octaose and nonaose glycans. Thus, to our knowledge, we describe here for the first time monoclonal antibodies recognizing $N$-glycosidically linked oligomannosidic glycans.

Key words: monoclonal antibodies/nervous system/oligomannosidic glycans

\section{Introduction}

Oligosaccharides $\mathrm{N}$ - or $\mathrm{O}$-glycosidically linked to cell surface glycoproteins have only recently become recognized as having important functional roles not only in modulating, for example, the functional conformations of the protein moiety, but also as being directly involved in cell recognition and adhesion. Significant advances in understanding the functional roles for oligosaccharides have been made using carbohydrate-specific monoclonal antibodies. By means of this approach, the $\mathrm{L} 2 /$ HNK-1, L3, L4 and L5 carbohydrate epitopes have been detected and implicated in neural cell interactions. The L2/HNK-1 carbohydrate epitope is expressed by several neural cell adhesion molecules and by glycolipids of the peripheral and central nervous system (for a review, see Schachner, 1989; Jessell et al., 1990; Chou et al., 1991). This epitope has been identified as a $3^{\prime}$-sulphated glucuronic acid at the non-reducing end of glycolipids with a neolactosyl-type backbone (Chou et al., 1986; Ariga et al., 1987). It is involved in the migration of neural crest cells (Bronner-Fraser, 1987), the adhesion of astrocytes and neurons to laminin (Hall et al., 1993), the outgrowth of astrocytic and neuritic processes (Künemund et al., 1988), the preferential outgrowth of neurites from motor but not from sensory neurons (Martini et al., 1992), the homophilic binding of the neural cell adhesion molecule P0 (Griffith et al., 1992), and finally the binding to P- and
L-selectin (Asa et al., 1992) and to human serum amyloid $P$ protein (Loveless et al., 1992).

The L3 and L4 monoclonal antibodies recognize carbohydrate epitopes released from glycoproteins by treatment with endoglycosidase H (Fahrig et al., 1990). These epitopes have, so far, always been reported as being co-expressed by some cell adhesion molecules positive for the L2/HNK-1 carbohydrate, e.g. L1, MAG and PO, but not by other L2/HNK-1positive molecules such as NCAM, J1/janusin (previously designated $\mathrm{J} 1-160 / 180$ ) and $\mathrm{J} 1 /$ tenascin. AMOG is the only adhesion molecule thus far found to carry the L3 and L4, but not the L2/HNK-1, epitope. Several other identified (e.g. Thy-1) or unidentified glycoproteins from different cell types, organs or species express the L3 and L4 carbohydrates (Kücherer et al., 1987; Bajt et al., 1990; Fahrig et al., 1990). In short-term adhesion assays, the $\mathrm{L} 3$ antibody has been shown to inhibit neuron-neuron adhesion only, whereas the L4 antibodies also inhibited neuron-astrocyte adhesion, suggesting that the antibodies recognize different epitopes (Fahrig et al., 1990).

Finally, the L5 carbohydrate, whose structure is currently not known, is expressed by L1, Thy-1 and astrochondrin, a chondroitin sulphate proteoglycan (Streit et al., 1990, 1993). The monoclonal antibody against this carbohydrate inhibits the extension of astrocytic processes, as well as cerebellar granule cell migration in vitro in developing chicken embryos (Streit et al., 1993). The L5 antibody also inhibits neural induction and closure of the neural tube (Roberts et al., 1991).

In this paper, we present evidence that carbohydrates reacting with the $\mathrm{L} 3$ and $\mathrm{L} 4$ antibodies are $\mathrm{N}$-linked oligomannosidic glycans. Studies of the specificity of antibody binding revealed that $\alpha 1-3-$ and $\alpha 1-6$, but not $\alpha 1-2$-linked mannose residues are important structural features for recognition by both antibodies. Binding of the antibodies to the peripheral myelin glycoprotein $\mathrm{P0}$, whose $N$-glycosidically linked oligosaccharides contain a fucose residue at the innermost $N$-acetylglucosamine (GlcNAc) (Field et al., 1992), is only weak and strongly increased after removal of the fucose with fucosidase. The fact that $\mathrm{L} 3$ and L4 antibodies have been shown to bind to neural cell surfaces, to inhibit cell adhesion and neurite outgrowth (Kücherer et al., 1987; Fahrig et al., 1990), and to interfere with the interaction between $\mathrm{Ll}$ and NCAM (Horstkorte et al., 1993), implicates the involvement of oligomannosidic glycans in important functional roles.

\section{Results}

Monoclonal LS and LA antibodies recognize oligomannosidic glycans

For the structural analysis of the $N$-glycosidically linked glycans which are recognized by $\mathrm{L} 3$ and $\mathrm{L} 4$ antibodies, we used oligosaccharides of AMOG released by endoglycosidase $\mathrm{H}$. Treatment of AMOG with this enzyme resulted in a complete removal of the epitopes recognized by both antibodies (Figure 


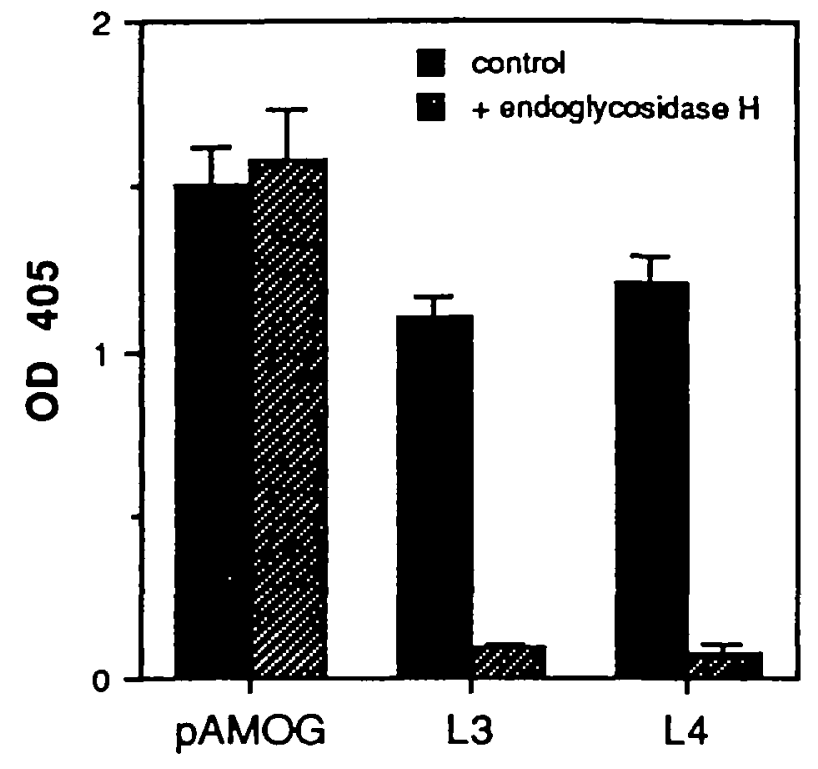

Fig. 1. Determination of the reactivity of polyclonal AMOG antibodies (pAMOG) and monoclonal L 3 and L4 antibodies (L3, L4) with AMOG with (+ endoglycosidase $\mathrm{H}$ ) or without endoglycosidase $\mathrm{H}$ treatment (control) as quantified by ELISA. The optical density at $405 \mathrm{~nm}$ (OD 405) of the reaction products with HRP-conjugated secondary antibodies is shown. Mean values \pm SDs of one representative out of three experiments carried out in quintuplicate are shown.

1). The advantage of using AMOG as a source of oligosaccharides for the L3/LA epitopes is that endoglycosidase $\mathrm{H}$ treatment of AMOG produces by far the largest shift in apparent molecular weightt, as compared to other glycoproteins (Bajt et al., 1990; Fahrig et al., 1990). From the rectuction in apparent mol. wt from 50 to $35 \mathrm{kDa}$ (Antonicek et al., 1987) and the calculated mol. wt for the protein backbone of $32 \mathrm{kDa}$
(Gloor et al., 1990), it can be estimated that $\sim 80 \dot{\%}$ of $\mathrm{N}$-linked oligosaccharides of AMOG are of the oligomannosidic and/or hybrid type. We could therefore expect to isolate reasonable quantities for the structural analysis of L3- and L4-positive oligosaccharides.

After the removal of protein, enzyme and salt on a Biogel P2 polyacrylamide column, released oligosaccharides were reduced with sodium borohydride, permethylated and submitted to fast-atom bombardment mass spectrometry (FAB-MS). Only three molecular $\left[\mathrm{M}+\mathrm{H}^{+}\right]$ions at $\mathrm{m} / \mathrm{z}=1328,1532$ and 1736 , with a relative abundance of $5: 2: 1$, could be detected, which correspond to oligosaccharides containing one $N$-acetylhexosamine and 5, 6 or 7 hexoses (Figure 2). Hybrid-type glycans, which could also be released by endoglycosidase $H$, would contain at least one more $N$-acetylhexosamine instead of hexose (Hex) and thus give rise to characteristically different molecular ions; these were not observed. The same glycan composition and distribution was obtained after peracetylation of oligosaccharides released from AMOG by endoglycosidase $H$, and an almost identical profile of molecular ions was observed for oligosaccharides released from L1 by endoglycosidase $\mathrm{H}$ (not shown). From the known biosynthesis of $N$-glycans (Kornfeld and Kornfeld, 1985) and the mode of action of endoglycosidase $\mathrm{H}$ (Tarentino et al, 1978), we conclude that the hexoses occurring in the identified oligosaccharides correspond to penta-, hexa- and heptamannosidic structures.

We further prepared neoglycolipids of oligomannosidic glycans, which in contrast to free oligosaccharides bind well to the plastic of microtitre wells so that the reactivity with antibodies can be measured by enzyme-linked immunosorbent assay (ELISA). Oligosaccharides released by endoglycosidase $\mathrm{H}$ from AMOG yielded neoglycolipids reacting with the $\mathrm{L} 3$ antibody (Figure 3) and, similarly, so did oligosaccharides from bovine RNase $B$, which is known to carry only oligomannosidic oligosaccharides (Liang et al., 1980). No immunoreactivity

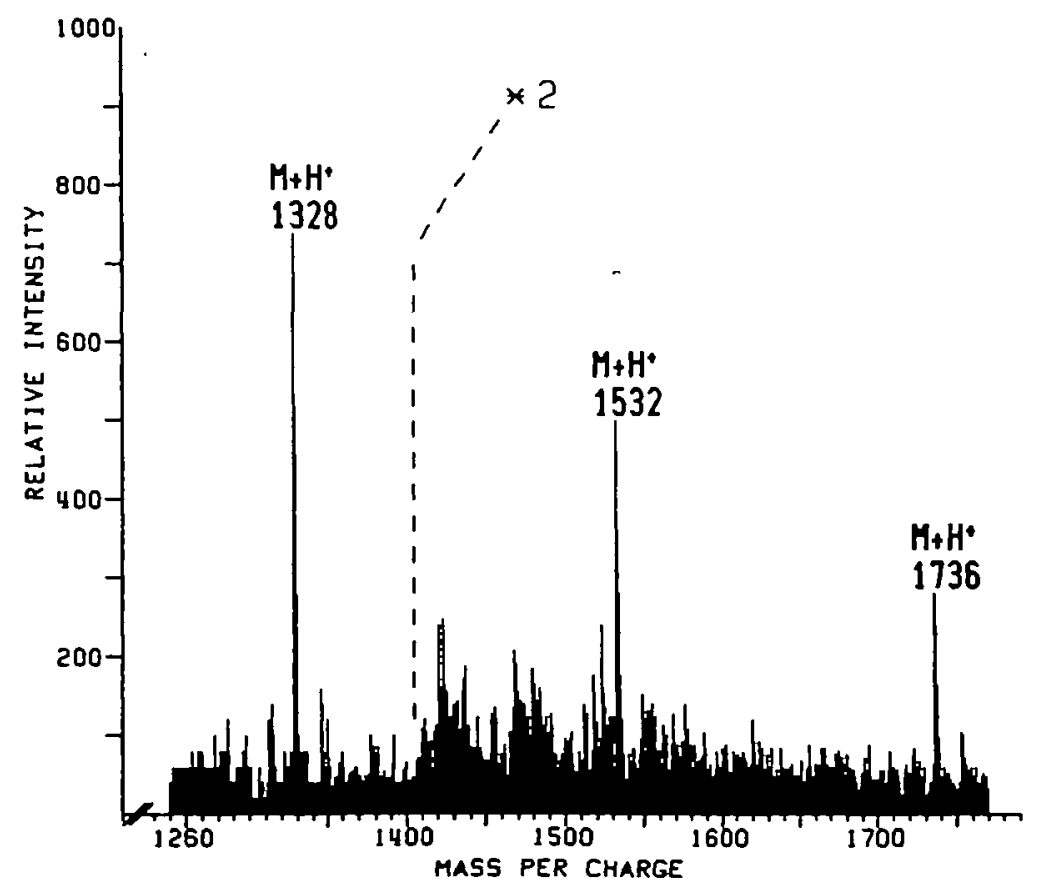

Fig. 2. Positive-ion FAB-MS of rectuced and permethylated oligosaccharides released by endoglycosidase $H$ from AMOG. Relative intensities of molecular $\left[\mathrm{M}+\mathrm{H}^{+}\right]$ions corresponding to $\mathrm{Hex}$, , HexNAc-ol are shown. No significant fragments were observed in the mass range < 1200 amu. 


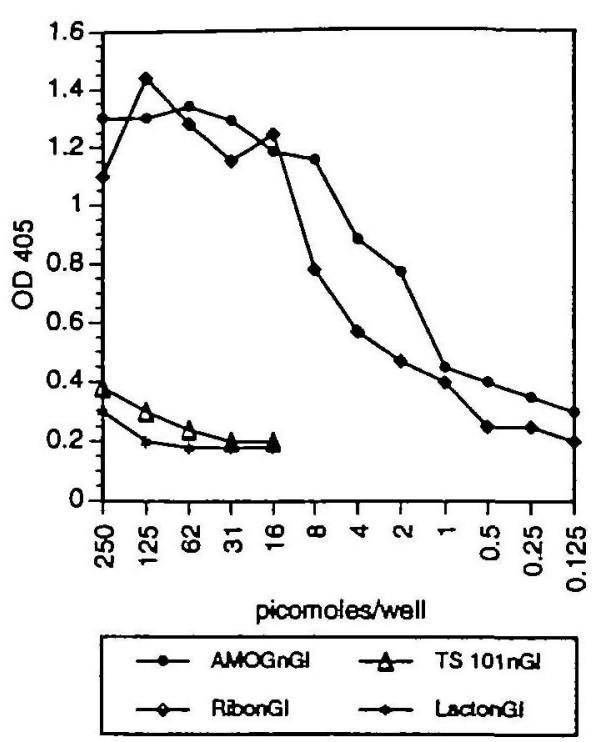

Fig. 3. Reactivity of L3 and L4 antibodies (L3, L4) with neoglycolipids as quantified by ELISA (AMOGnGl, RibonGl: neoglycolipids of oligosacctarides released from AMOG and RNase B by endoglycosidase $H$, respectively; TS10 $1 \mathrm{nGl}$, LactonGl: nooglycolipids containing the trisaccharide Gal-GleNAc-Man and lactose, respectively). Wells were coated with neoglycolipids in serial 1:1 dilution from $250 \mathrm{pmol} /$ well. Reactivity with the $L 3$ antibody was determined by measuring the optical density at $405 \mathrm{~nm}(\mathrm{OD} 405)$ of the reaction products with the HRP-conjugated secondary amibodies. One representative out of three experiments carried out in triplicate is shown, SDs were $<5 \%$.

was observed with lactosylneoglycolipid and a neoglycolipid containing the trisaccharide Gal-GIcNAc-Man (galactose$\beta 1-4-N$-acetylglucosamine- $\beta 1-4$-mannose; TS101) (Figure 3). The same result was obtained with the L4 antibody (not shown).

On thin-layer chromatograms, neoglycolipids derived from AMOG or RNase B separated into three bands, of which the fastest co-migrated with the neoglycolipid derived from Man5GlcNAc-oligosaccharide (Figure 4). The two more slowly migrating bands should correspond to Man 6 GlcNAc- and Man, GlcNAc-neoglycolipids, in agreement with the structural evidence from the $\mathrm{FAB}$ mass spectrum. Immunostaining of TLC plates with the monoclonal L3 antibody gave a strong

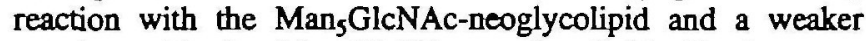
reaction with the $\mathrm{Man}_{6} \mathrm{GlcNAc}$-neoglycolipid. No immunoreactivity was observed with the Man,GlcNAc-neoglycolipid (Figure 4). This is probably not only due to the lower abundance of this compound in the mixture, as seen in the orcinol-stained chromatogram (Figure 4B), but also to the

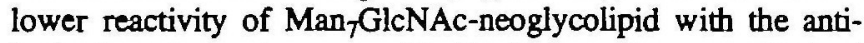
body (see the next paragraph). Similar results were obtained with the LA antibody (not shown).

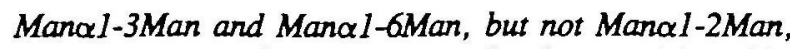
are important carbohydrate units for the reactivity with the monoclonal $L 3$ and $L A$ antibodies

In order to identify the structural features necessary for antibody recognition, neoglycolipids were prepared individually from oligosaccharides of known structures containing $5,6,7$, 8 or 9 mannoses (Figure 5). Under the conditions used, Man 5 GlcNAc - to $\mathrm{Man}_{8} \mathrm{GlcNAc}_{2}$-oligosaccharides were converted quantitatively into their neoglycolipids, whereas $\sim 50 \%$ of the

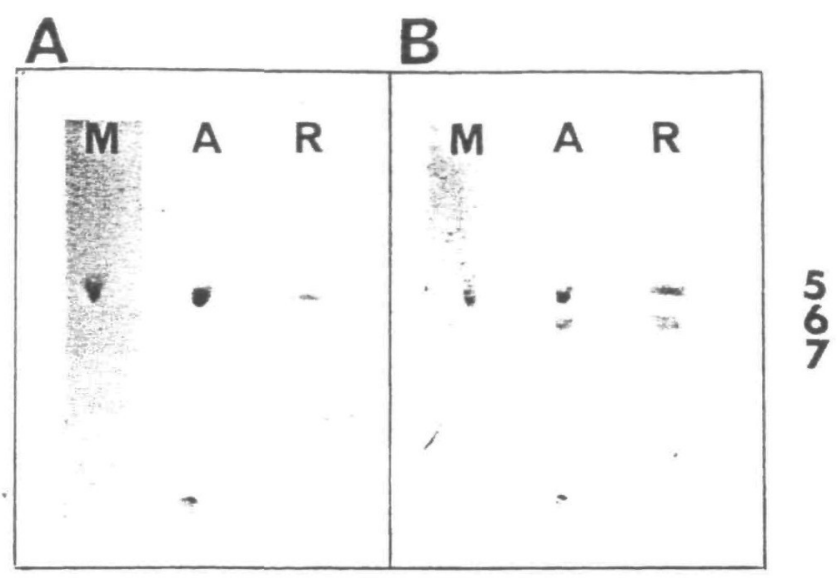

Fig. 4. (A) Binding of L3 antibady to Mang GlcNAc-neoglycolipid (M, $3 \mu \mathrm{g}$ ) and neoglycolipids of oligosaccharides released by endoglycosidase $H$ from AMOG (A, $5 \mu \mathrm{g})$ or RNase B (R, $3 \mu \mathrm{g})$, as detected by TLC immunostaining. After chromatography of neoglycolipids, TLC plates were incubated with L3 antibody and secondary HRP-conjugated antibodies. Binding of antibodies was visualized with chloronaphthol. (B) Detection of neoglycolipids by staining with orcinol; 5, 6, 7 at the right margin designate neoglycolipids containing 5, 6 and 7 mannoses.

$\mathrm{Man}_{9} \mathrm{GlCNAc}_{2}$-oligosaccharide. remained underivatized, as estimated by orcinol staining of thin-layer chromatograms (not shown). This was taken into account when equimolar amounts of the neoglycolipids were coated in microtitre plate wells for the comparison of their reactivities with the antibodies. Interestingly, an increasing reactivity with the $\mathrm{L} 3$ antibody (Figure 6) and the LA antibody (not shown) was observed with a decreasing number of mannoses. The $\mathrm{Man}_{9} \mathrm{GlcNAc}_{2}-\mathrm{neo}$ glycolipid gave only an extremely low reactivity. A significant increase in reactivity was observed from the $\mathrm{Man}_{9} \mathrm{GlNNAc}_{2}-$ to the $\mathrm{Man}_{8} \mathrm{GlcNAC}_{2}$ - and from the $\mathrm{Man}_{8} \mathrm{GlcNAC}_{2}$ - to the $\mathrm{Man}_{7} \mathrm{GlcNAC}_{2}$-neoglycolipid, whereas only small further increases in antibody reactivity were seen for $\mathrm{Man}_{6} \mathrm{GlcNAc}_{2}-$ and $\mathrm{Man}_{5} \mathrm{GlCNAC}_{2}$-neoglycolipids. From these observations, it is concluded that $\alpha 1-3-$ and $\alpha 1-6$-linked mannose residues exposed at the non-reducing end of the oligosaccharides are recognized by the antibodies. $\alpha 1-2$-linked mannose at the nonreducing end of oligosaccharide structures was, if at all, only weakly recognized by the antibodies, and also appeared to block the recognition of internal $\alpha 1-3-$ and $\alpha 1-6$-linked mannose residues.

After treatment of $\mathrm{Man}_{5}$ Glc-NAc-neoglycolipid with jack bean mannosidase, reactivity with the $\mathrm{L} 3$ antibody was similar to the reactivity of the $\mathrm{Man}_{8} \mathrm{GlcNAc}_{2}$-neoglycolipid, indicating that further removal of mannose units leads to a reduction in immunoreactivity (Figure 6). Similar results were obtained for the LA antibody (not shown). Negative-ion mass spectrometric analysis of the product of the mannosidase-treated $\mathrm{Man}_{5}$ GlcNAc-neoglycolipid gave only one detectable molecular $\left[\mathrm{M}-\mathrm{H}^{+}\right]$ion at $\mathrm{m} / \mathrm{z}=1219$, corresponding to $\mathrm{Man}_{2}$ GlcNAcneoglycolipid (not shown).

Fucose linked to the innermost $N$-acetylglucosamine of $N$-linked oligosaccharides inhibits recognition by the $L 3$ and $L A$ antibodies

The major glycoprotein from the peripheral nervous system, P0, has been shown to carry the $\mathrm{L} 3$ and $\mathrm{L} 4$ epitopes (Bollensen et al., 1988; Fahrig et al., 1990). Treatment of P0 with 
$\operatorname{Man} 5$

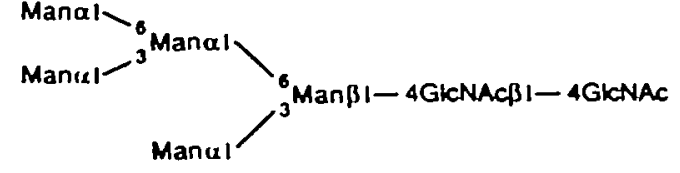

Man6

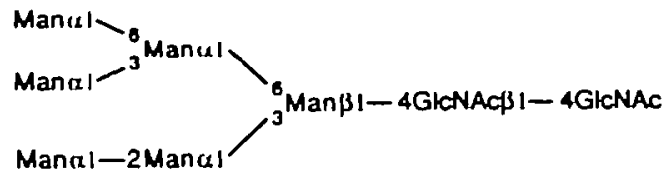

$\operatorname{Man7}$

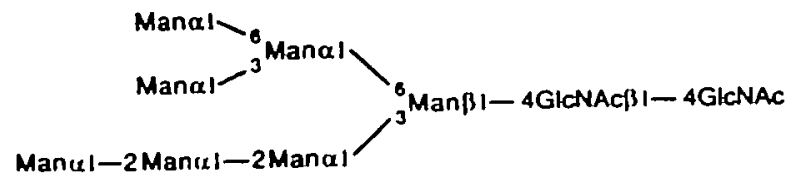

$\operatorname{Man} 8$

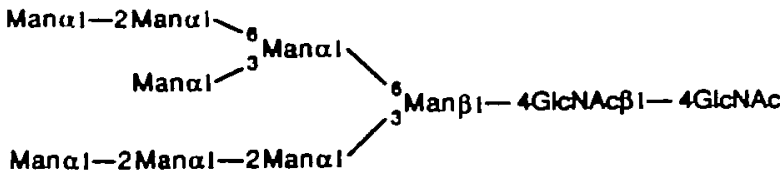

Mang

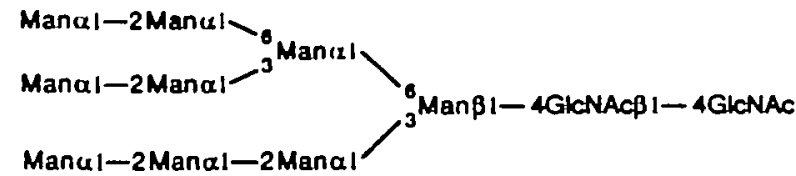

Fig. 5. Structures of oligomannosidic glycans carrying 5, 6, 7,8 or 9 mannose residues (Mans-Mang) used for the preparation of defined neoglycolipids. According to the supplier's NMR analysis, the structures shown for Man7 and Man8 represent $70 \%$ and $80 \%$, respectively, of the isomer mixtures.

$\alpha$-fucosidase from Charonias lampas increased the binding of the L3 antibody 12-fold (Figure 7). No significant increase in $\mathrm{L} 3$ immunoreactivity was observed for L1 and for AMOG after treatment with fucosidase. The same results were obtained with the L4 antibody (not shown). As P0 carries $\alpha$-fucose only at the innermost GlcNAc (Field et al., 1992; Uyemura and Kitamura, 1991), we believe that fucose in this position may prevent binding of $\mathrm{L} 3$ and $\mathrm{L} 4$ antibodies to mannosidic glycans by steric hindrance.

Maintenance of cerebellar neurons in culture in the presence of swainsonine increases $L 3$ and $L A$ immunoreactivity

The oligomannosidic L3 and L4 epitopes have been detected by indirect immunofluorescence studies at the cell surface of cerebellar neurons (Kücherer et al., 1987). The expression of the epitopes should therefore be increased by treatment of cells with the glycan processing inhibitor swainsonine, which blocks Golgi mannosidase $\Pi$, thus causing an accumulation of oligomannosidic and hybrid-type glycans (Tulsiani et al., 1990).
When cells were maintained in vitro in the absence of inhibitors; expression of the L3 epitope could be observed on most cells (>90\%) and on their processes. Maintenance of these cell cultures in the presence of swainsonine for 2 days led to a strong increase of L 3 expression (Figure 8). Cell viability was unaffected by this treatment, as judged by the morphological appearance of the cultures, and seems therefore not to depend on the expression of complex-type carbohydrates, which is strongly reduced under the same culture conditions (Hall et al., 1993). Similar results were obtained with the L4 antibody (not shown).

\section{Discussion}

In this study, we have identified the carbohydrate epitopes recognized by monoclonal L3 and L4 antibodies. Only three molecular ions could be detected by mass spectrometric analysis of the endoglycosidase $\mathrm{H}$-released oligosaccharides from AMOG, which had previously been shown to contain the 


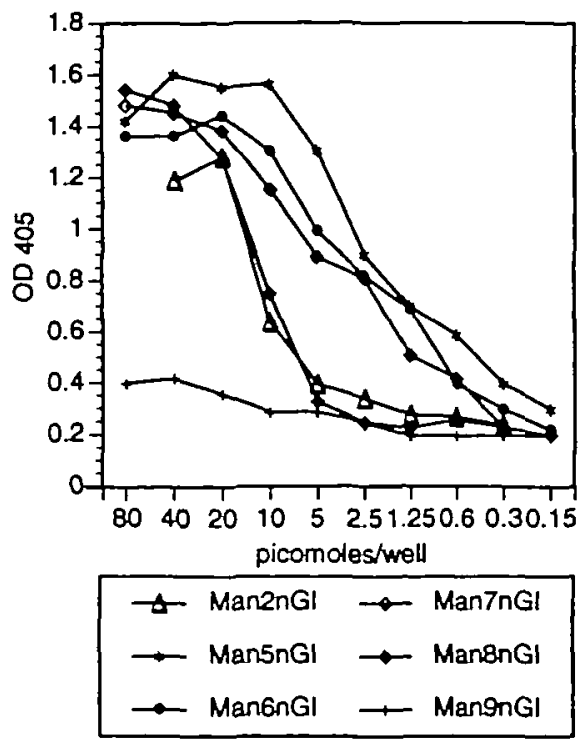

Fig. 6. Reactivity of $\mathrm{L}_{3}$ antibody (L3) with $\mathrm{Man}_{2},-\mathrm{Man}_{5}-, \mathrm{Man}_{6}-, \mathrm{Man}_{-}-$, $\mathrm{Man}_{4}$ - and Man $\mathrm{GlcNAC}_{2}$-neoglycolipids (Man2, $5,6,7,8,9 \mathrm{nG}$ ), as quantified by ELISA. Man2nGl was obtained from Man5nGl after jack bean mannosidase trearment, as determined by FAB-MS (not shown). Neoglycolipids were coated in a $1: 1$ serial dilution from $80 \mathrm{pmol} /$ well on. Reactivity with the $\mathrm{L} 3$ antibody was determined by measuring the optical density at $405 \mathrm{~nm}(\mathrm{OD} 405)$ of the reaction products with the HRP-conjugated secondary antibodies. One representaive out of three experiments carried out in triplicate is shown; SDs were $<5 \%$.

epitopes recognized by the $\mathrm{L} 3$ and $\mathrm{L} 4$ antibodies (Kücherer et al., 1987; Fahrig et al., 1990). These molecular ions correspond to oligosaccharides composed of one $\mathrm{N}$-acetylglucosamine and 5, 6 or 7 mannoses. Thus, only oligomannosidic glycans are released from AMOG and, as a consequence, the L3 and L4 antibodies must recognize oligomannosidic structures.

The mass spectrometric results were corroborated by TLC immunostaining and ELISA, showing that the antibodies react with neoglycolipids derived from the glycans of AMOG, RNase $B$ and from oligomannosidic glycans of defined structures, but not with neoglycolipids containing other neutral glycans. Obviously, both antibodies do not require the intact di- $N$ acetylglucosamine unit for recognition because the terminal $\mathrm{N}$-acetylglucosamine residue is cleaved by endoglycosidase $\mathrm{H}$ treatment and the $N$-acetylglucosamine residue linked $\beta 1-4$ to the mannotriose core is modified during the derivatization of oligosaccharides to neoglycolipids (Tang et al., 1985). The binding of the L3 and L4 antibodies to neoglycolipid containing defined oligomannosidic glycans increased from $\mathrm{Man}_{9^{-}}$to $\mathrm{Man}_{5}$-neoglycolipid, i.e. with decreasing numbers of mannoses paralleling the decreasing number of $\alpha 1$-2-linked and increasing number of $\alpha 1-3-$ and $\alpha 1-6$-linked mannoses at the non-reducing end. The most straightforward interpretation of this result is that terminally exposed $\alpha 1-3-$ and $\alpha 1-6$-linked mannose residues are required for antibody binding, whereas terminal $\alpha 1$-2-linked mannose seems not to be recognized and, in addition, to prevent the recognition of internally located $\alpha 1-3-$ and $\alpha 1-6$-linked mannose residues. Whether the antibodies bind better to the $\alpha 1-3-$ or $\alpha 1-6$-linked glycans cannot be distinguished in our assay. Interestingly, recombinant interleukin IL-2 binds with similar preference to oligomannosidic glycans as the L3 and L4 antibodies. The binding of IL-2 to uromodulin

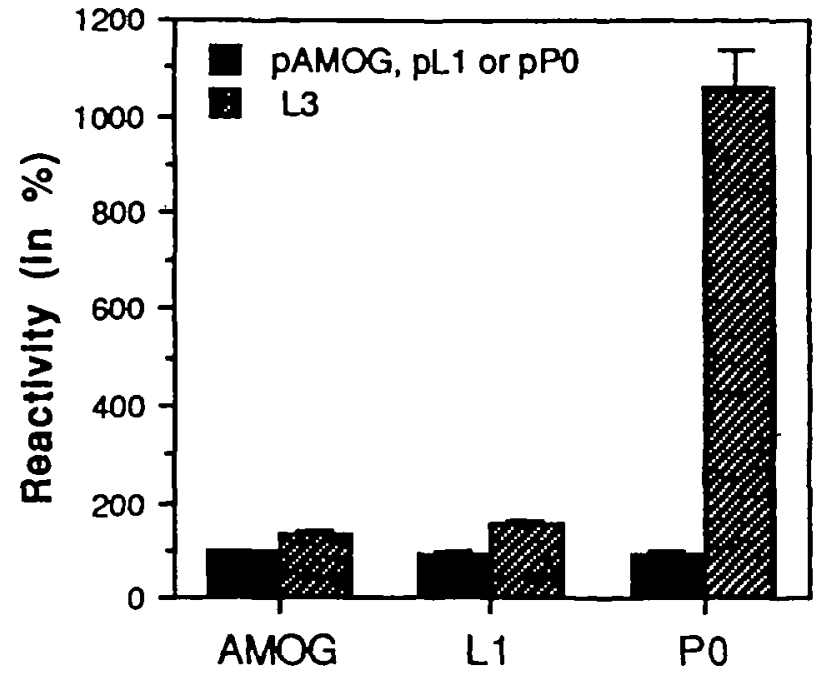

Flg. 7. Reactivity of $\mathrm{L} 3$ antibody (L3) after fucosidase treatment of AMOG, Ll or PO, as quantified by ELISA. The optical density at $405 \mathrm{~nm}$ of the reaction products with the HRP-conjugated secondary antibodies is shown. Reactivity of monoclonal $\mathrm{L} 3$ (L3) and polyclonal AMOG, LI or P0 antibodies ( $\mathrm{PAMOG}, \mathrm{pLl}$ or $\mathrm{pPO}$ ) is expressed in percent, with reactivity for non-treated samples set to $100 \%$. Mean values \pm SDs from one representative out of three independent experiments carried out in triplicate are shown.

was inhibited by $\mathrm{Man}_{5}$ - and $\mathrm{Man}_{6}$-glycopeptides at micromolar concentrations, whereas the Mang-glycopeptide was ineffective as an inhibitor (Sherblom et al., 1989).

Another interesting aspect of the specificity of the L3 and L4 antibodies is the strong increase in antibody reactivity which was only observed with PO, but not with AMOG or L1, after treatment with $\alpha$-L-fucosidase. The glycan structures of PO have been shown to be almost exclusively of the hybrid type carrying fucose at the innermost $N$-acetylglucosamine, but not in other positions (Uyemura and Kitamura, 1991; Field et al., 1992). This observation suggests (i) that the mannosidic branch of hybrid-type structures may be sufficient for immunoreactivity and (ii) that fucose in this location inhibits the recognition by the L 3 and $\mathrm{L} 4$ antibodies. The $\alpha 1-6$ glycosidic linkage, which seems to be part of the epitope recognized by the antibodies, is thought to confer high rotational freedom on branched oligosaccharides. It is, therefore, likely that the antibodies bind preferably to a specific conformation in which only non-fucosylated structures can exist. This could possibly be a conformation also described as the 'broken wing' conformation (Montreuil, 1984), in which the $\alpha 1-6$ branch folds back towards the $N$-glycosidic linkage and which is probably perturbed when a fucose is attached to the terminal $N$-acetylglucosamine.

In the present suudy, the L3 and L4 antibodies showed no difference in their reactivity towards all compounds tested. Earlier results, however, indicated that the antibodies recognize different epitopes on L1 because they did not compete with each other for binding to their epitopes (Fahrig et al., 1990). It is, therefore, difficult to understand why we observed the same pattern of reactivity of both antibodies with different oligomannosidic neoglycolipids. One possible reason could be that, through interaction with the protein backbone, the oligomannosidic glycans exist as distinct conformers which are recognized by either the L 3 or the LA antibody.

Polyclonal antibodies raised against yeast mannans have been described previously to recognize Man $\alpha 1-3$ Man structures 

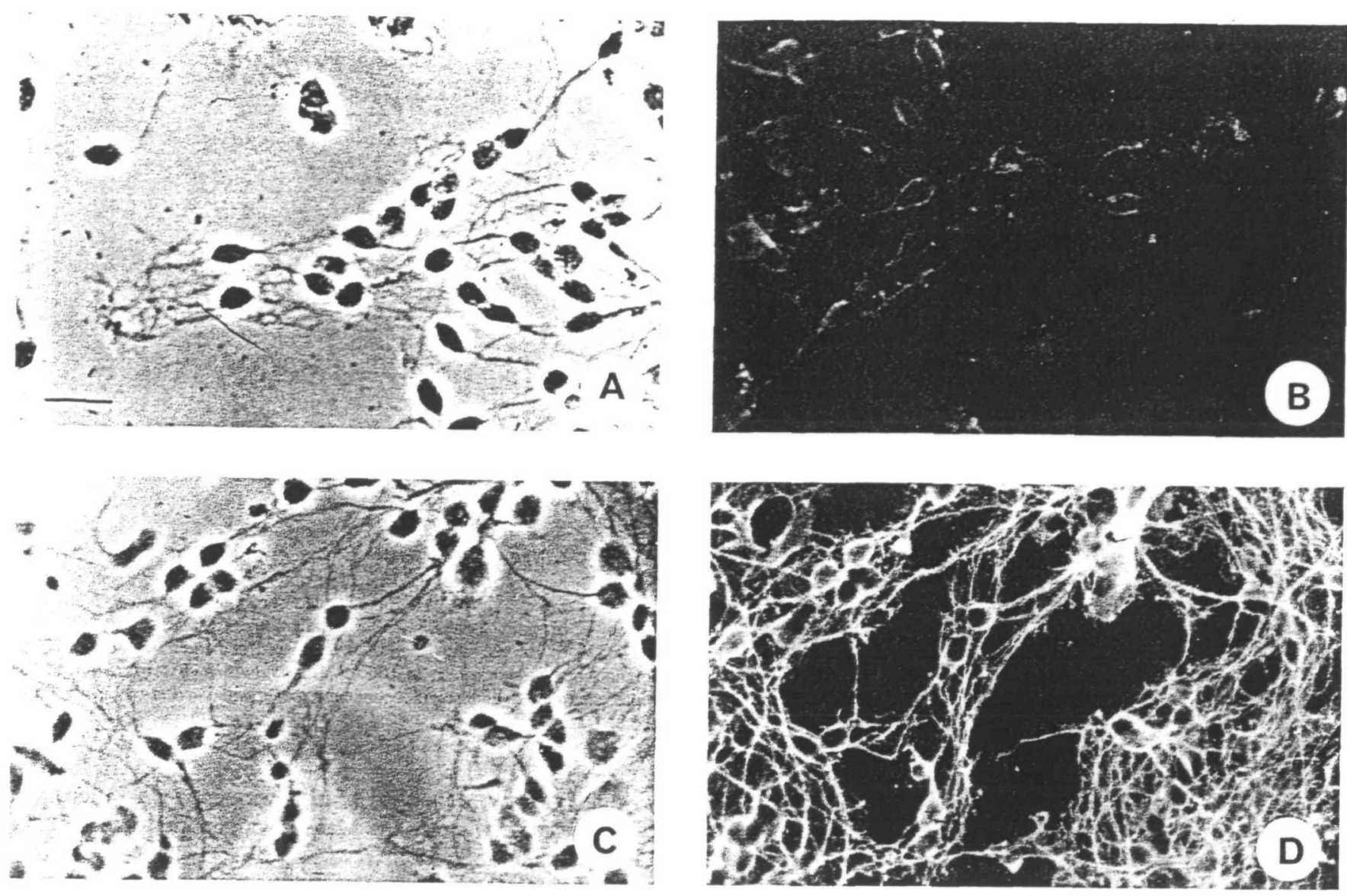

Fig. 8. Immunocytochemical detection of the $\mathrm{L} 3$ epitope in cultures of cerebellar neurons. Indirect immunofluorescence staining of live cells in monolayer culture from early postnatal mouse cerebella maintained for 2 days in vitro was carried out with monoclonal L3 antibody. Cultures were maintained in the presence $(C, D)$ or in the absence $(A, B)$ of the glycosylation processing inhibitor swainsonine. Note the increased L3 expression in (D) as compared to (B) The phase-contrast micrographs corresponding to furorescence images (B) and (D) are shown in (A) and (C), respectively. The bar in (A) represents $10 \mu \mathrm{m}$ for A-D.

(Nakajima et al., 1978; Hamada et al., 1981). To our knowledge, the $\mathrm{L} 3$ and $\mathrm{L} 4$ antibodies are the first monoclonal antibodies described to recognize oligomannosidic glycans. Lectins are yet other carbohydrate-binding proteins found in bacteria, plants and animals, and amongst them are several mannose-specific lectins (Lis and Sharon, 1991; Taylor et al., 1992). The function of carbohydrate-lectin interactions in plants is largely unknown, but in mammals it has been shown that they play an important role in host defence mechanisms against infectious microorganisms. Bacteria, for example, interact through these glycans with mannose-binding proteins on phagocytic cells (Ofek and Sharon, 1988). Conversely, bacteria may bind through lectins they express to mannosidic glycans carried by the leucocyte adhesion molecule CD11/ CD18, an integrin (Gbarah et al., 1991). These processes, termed lectinophagocytosis, are antibody-independent responses relying on interactions between cell surface-exposed carbohydrates and lectins (Ofek and Sharon, 1988).

That oligomannosidic glycans can be expressed at cell surfaces and are not merely required as precursors of complextype oligosaccharides during the biosynthesis of glycoproteins in the endoplasmic reticulum (ER; Kornfeld and Kornfeld, 1985), has been demonstrated by immunofluorescence studies with the L3 and L4 antibodies. Neurons, subpopulations of astrocytes and oligodendrocytes showed cell surface reactivity with both antibodies (Kücherer et al., 1987; Fahrig et al.,
1990). The antibodies also inhibited cell adhesion and outgrowth of processes from neurons and astrocytes, suggesting that the expression of oligomannosidic glycans at the cell surface is of functional importance (Fahrig et al., 1990). This assumption is strongly supported by the observation that the oligomannosidic glycans themselves, when added to the culture medium of cerebellar neurons, drastically inhibited neurite outgrowth (Horstkorte et al., 1993). Several findings provide evidence that the inhibition of neurite outgrowth is the result of a disturbed association of L1 with NCAM via oligomannosidic glycans carried only by L1, but not by NCAM, implicating oligomannosidic glycans in important cell recognition and adhesion processes (Horstkorte et al., 1993).

Apart from Ll and AMOG, a large number of glycoproteins have been shown to carry oligomannosidic glycans, either by reactivity with lectins, the $\mathrm{L} 3$ and $\mathrm{L} 4$ antibodies or by structural analysis, e.g. chorionogonadotrophin (Blithe, 1990), integrins (Pesheva et al, 1987; Asada et al., 1991), myelin-associated glycoprotein (MAG; Fahrig et al., 1990), ovalbumin (Tai et al., 1977), PO (Bollensen et al., 1988), RNase B (Liang et al., 1980), Thy-1 (Parekh et al., 1987; Fahrig et al., 1990), thyroglobulin (Arima et al., 1972) and uromodulin (Sherblom et al., 1987). Interestingly, some of these glycoproteins have been shown to exist in association with other proteins. Functionally important associations mediated by oligomannosidic glycans are so far only known for L1 and NCAM and for the 
subunits of human chorionogonadotrophin (Blithe, 1990; Horstkorte et al., 1993). It remains to be seen whether these glycans play a role in the non-covalent linkage between other cell surface glycoproteins, as for example the subunits of thyroglobulin, the $\alpha$ - and $\beta$-subunits of integrins or AMOG, the $\beta 2$-subunit of the $\mathrm{Na} / \mathrm{K}$-ATPase and the catalytically active $\alpha$-subunit (Gloor et al., 1990; Schmalzing et al., 1992).

Association of proteins can take place during their biosynthesis in the ER (Hurtley and Helenius, 1989), where only oligomannosidic glycans exist. The possibility of subunit association in the ER, together with the locally restricted synthesis of different types of oligosaccharides in the compartments of the ER and Golgi apparatus, provides a basis for the hypothesis that the interaction between molecules like L1 and NCAM may take place in the ER. This association may prevent trimming and processing of oligomannosidic glycans by glycosidases and glycosyltransferases by steric hindrance. As a result, the oligomannosidic glycans would pass through the Golgi apparatus unmodified and reach the cell surface. It is possible, therefore, that the oligomannosidic glycan-mediated association of proteins represents a more general mechanism for the assembly of cell surface expressed and secreted proteins.

\section{Materials and methods}

\section{Antibadies}

Monoclonal L3 and LA antibodies (Kuicherer et al, 1987; Fahrig et al, 1990), both of the IgM subclass, were either used as ascites or as immunoaffinitypurified antibodies using a monoclonal MARK-1 antibody column reacting with rat Ig tappa chain (Bazin, 1982). Polyclonal antibodies were prepared in rabbits against AMOG (Antonicet e al., 1987), PO (Schneider-Schaulies et al. 1990) and L1 (Mertini and Sctractmer, 1986). Horseradish peroxidase (HRP)conjugated secondary antibodies directed against rat IgG and IgM or rabbit $18 G$, as well as fluorescein isothiocyanate-conjugated secondary antibodies, were purchased from Jackson Immunochemicals (Hamburg, FRG).

\section{Giycoprateins}

AMOG and L1 were immunoaffinity purified from detergent lysates of crude membrane fractions from adult mouse brain using monoclonal amtibody columns (Rathjen and Schachner, 1984; Antonicek et al., 1987). PO was obtained from human sciatic nerve myelin according to Kitamura et al. (1976). RNase B and pronase were purchased from Sigmra.

\section{Isolarion of oligosaccharides}

Oligosactharides were released from AMOG or RNase B either by hydrazinolysis (Takasaki et al., 1982) or by treatment with endoglycosidase $H$ (Bochringer Mannheim). For the enzymatic release, $500 \mu \mathrm{g}$ of immunoaffinitypurified AMOG were incubated for $24 \mathrm{~h}$ at $37^{\circ} \mathrm{C}$ with $50 \mathrm{mU}$ endoglycosidase $\mathrm{H}$ in $1 \mathrm{ml}$ of $50 \mathrm{mM}$ sodium acecate buffer ( $\mathrm{pH} 5.5$ ). The complecteness of the reaction was monitored by ELISA (see below). The reaction products were purified by Biogel P2 (Biorad) column chromatography with $1 \%$ acetic acid in water as eluent. Oligosaccharide-containing fractions were detected by silica gel TLC (Merck, catalog no. 5721) with butanol/ethanol/water/acetic acid/ pyridine $(10 / 100 / 30 / 3 / 10$, by vol.) as solvent. Orcinol-positive fractions beyond the void volume of the column were collected, neutralized with pyridine and the solvents removed using a rotary evaporator.

\section{Mass spectrometry}

FAB-MS pas performed on a ZAB HF mass spectrometer (VG Analytical, Manchester, UK) in the positive-ion mode on glycans relessed by endoglycosidase $\mathrm{H}$ treatment, followed by peracetylation or permethylation (Egge and Peter-Katalinic, 1987) and in the negative-ion mode on neoglycolipids derived from native glycans using thioglycerol as a matrix. Spectra were acquired as single scans in the upscan mode using an AMD DP10 data systern equipped with SAMII (KWS) hardware and SUSY software (AMD Intectra, Beckeln, FRG),

\section{Synthesis of neoglycolipids}

Neoglycolipid derivatives of the following carbohydrates were prepared: oligosaccharides from $A M O G$ released by endoglycosidase $H$ or from RNase $B$ released either by hydrazine or endoglycosidase $\mathrm{H}$ as described above, lactose and TS101 (the trisaccharide galactose- $N$-acetylgl lucosamine-mannose). Furthermore, oligomannosidic glycans of defined structures containing 5, 6, 7, 8 or 9 mannose residues (Man, GlcNAC, $_{2}$ released from thyroglobulin, Oxford GlycoSystems; see Figure $S$ for structures) and MarsGlcNAc (a gift from A.Haselbeck, Boehringer Mannheim) were derivatized to neoglycolipids. Neoglycolipid synthesis was performed mainly according to the procedure described by Stoll et al. (1988). Briefly, $500 \mu \mathrm{g}$ of oligosaccharides in $20 \mu \mathrm{l}$ methanol/water $(1 / 1, \mathrm{v} / \mathrm{v})$ were mixed with $4 \mathrm{mg}$ dipalmitoyl-phosphatidylethanolamine (Sigma) dissolved in $800 \mu$ chloroform/methanol $(1 / 1, v / v)$. After incubation at $60^{\circ} \mathrm{C}$ for $2 \mathrm{~h}, 1 \mathrm{mg}$ of sodium cyanoborohydride in $100 \mu \mathrm{l}$ methanol was added and the reaction continued for up to 5 days. The progress of the reaction was monitored by TLC. The chromatogram was first developed with chloroform/methanol/water $(105 / 100 / 28$, by vol.) until the front had reached about $2 / 3$ across the plate and after drying, with chloroform $/$ methanol/ water $(75 / 125 / 4$, by vol.) until the top of the thin-layer plate. Glycolipids were visualized by staining with orcinol reagent.

The neoglycolipids were purified on Sephadex LH 20 (column size $140 \times 18$ $\mathrm{mm}$; Pharmacia) with chloroform/methanol/water $(5 / 5 / 1$, by vol.) as eluent and then on Latrobeads (column size $80 \times 18 \mathrm{~mm}$; Macherey \& Nagel, Düren, FRG), first with chloroform/methanol/water $(75 / 25 / 4$, by vol.) until the underivarized phosphatidylethanolamine eluted, and finally with chloroform methanol/water (105/100/28, by vol.). The fractions from each column were analysed by TLC and the neoglycolipid-containing fractions pooled.

Synthesis of neoglycolipids with mannosidic glycans of defined structures was carried out with $10 \mathrm{nmol}$ of each compound. All solvents and reagents were scaled down to $1 / 20$ of the level described in the procedure above.

Determination of antibady binding to neoglycolipids by $T L C$ immunostaining

Neoglycolipids derived from $\mathrm{Man}_{3} \mathrm{GlCNAC}_{2}(-3 \mu \mathrm{g})$, from oligosaccharides of AMOG $(-5 \mu \mathrm{g})$ and oligosaccharides of RNase B $(-3 \mu \mathrm{g})$ were chromato-

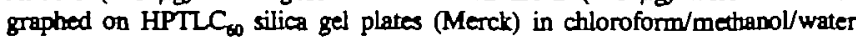
$(105 / 100 / 28$, by vol.). Incubation of TLC plates with antibodies was essentially carried out as described by Felding-Haberman et al (1986) with the modification that the plates were incubated with the first antibody $(50 \mu \mathrm{g} / \mathrm{ml})$ at $4^{\circ} \mathrm{C}$ overnight and with the secondary HRP-conjugated antibody for $3 \mathrm{~h}$ at room temperature. After the development of the HRP reaction with 4-chloronaphthol, the TLC plate was washed three times with water, air dried and treated with acetone to remove the polyisobutyl-methacrylate. After drying, the plate was sprayed with orcinol and heated at $100^{\circ} \mathrm{C}$ for colour development.

\section{ELISA}

(i) Detemination of antibady binding to AMOG before and afier treatment with endoglycosidase $H$. AMOG was treated with endoglycosidase $\mathrm{H}$ is described above for the isolation of the oligosaccharides. As a control, the incubation of AMOG was carried out under identical conditions as for the enzymatic digestion, but in the absence of the enzyme. The incubation solutions were then diluted in $0.1 \mathrm{M}$ sodium bicarbonate to a concentration of 1 pg AMOG/ml and incubated in 96 well microtitre plates (Falcon, catalogue no. 3912) at $4^{\circ} \mathrm{C}$ overnight. After blocking for $1 \mathrm{~h}$ with $1 \%$ bovine serum albumin (BSA) in phosphate-buffered saline, pH 7.2 (PBS), wells were incubated for $3 \mathrm{~h}$ with appropriate dilutions of monoclonal $\mathrm{L} 3, \mathrm{~L} A(10 \mu \mathrm{g} / \mathrm{ml})$ or polyclonal AMOG antibodies $(100 \mu \mathrm{g} / \mathrm{ml})$. After washing of plates with PBS, incubation with HRP-conjugated antibodies to rabbit Ig or rat IgG and IgM for $2 \mathrm{~b}$ and another washing step, the HRP reaction was carried out as described by Bollensen $a$ al. (1988). The optical density of the HRP reaction product was measured at $405 \mathrm{~nm}$ using a Titertek Multiscan Plus (Flow). All incubations were carried out at room temperanire.

(ii) Determination of the binding of the $L 3$ and $L 4$ antibodies to $A M O G, L I$ and PO afier fucasidase treatment. AMOG, LI or PO $(10 \mu \mathrm{g})$ were dissolved in $200 \mathrm{\mu l}$ of $0.1 \mathrm{M}$ citrate/phosphate buffer (pH 4.0), and incubated for $48 \mathrm{~h}$ at $37^{\circ} \mathrm{C}$ with $15 \mathrm{mU} \alpha$-fucosidase from C. lampas (Seikagaku Kogyo, Japan; the enzyme is no longer available). For a control, the antigens or enzymes were incubated in the absence of enzyme or antigens, respectively, under otherwise identical conditions. The incubation solutions were diluted $1: 10$ in $0.1 \mathrm{M}$ sodium bicarbonate and the ELISA performed as described in (i) using monoctonal $\mathrm{L} 3$ and $\mathrm{LA}$, and polyclomal AMOG, $\mathrm{L} 1$ or $\mathrm{PO}$ antiboties.

(iii) Detection of neoghroolipids. Solutions of purified neoglyocolipids in ethanol were applied onto microtitre plates either at constant concentrations or serially diluted (see legends to Figures 3 and 6 for concentrations) and the ethanol 
evaporated at room temperature. After incubation of wells with $1 \%$ defatred BSA (Sigma, catalogue no. A 7030) in $0.1 \mathrm{M}$ sodium bicarbonate for $1 \mathrm{~h}$, incubation with $\mathrm{L} 3$ or L4 antibody for $3 \mathrm{~h}$ was followed by incubation with HRP-conjugated secondary antibodies to rat IgG and IgM for $2 \mathrm{~h}$, and the ELISA developed as described in (i). All steps were carried oul at room termperature. For the detection of $\mathrm{L} 3$ and $\mathrm{L} 4$ immunoreactivity after $\alpha$ mannosidase treatment, an aliquot of a $\mathrm{Man}_{3} \mathrm{GlNAC}_{2}$-neoglycolipid preparation $(-10 \mu \mathrm{g})$ was incubated for $48 \mathrm{~h}$ at $37^{\circ} \mathrm{C}$ with jack bean mannosidase (2 U; Sigma) in $10 \mathrm{mM}$ sodium acetate buffer ( $\mathrm{pH} 4.2$ ) containing $0.1 \mathrm{mM}$ zinc acetate. A control aliquot was incubated in paralled withour enzyme. After freeze-drying, the incubation mixtures were dissolved in $100 \mu 1$ of chloroform $/ \mathrm{methanol} /$ water $(100 / 105 / 28$, by vol.) and diluted $1: 100$ in ethanol. The ELISA was then performed as described above. In order to ensure that glycolipids remained bound to the plastic of the microtitre plates during the ELISA procecture, substrate-coated glycolipids ( $1 \mu \mathrm{g} / \mathrm{mI}$ ) were incubated for $6 \mathrm{~h}$ with $1 \%$ defatted BSA in PBS. After washing of the mictotite plates with distilled water, the coated glycolipids were redissolved in chloroform/methanol/ water (1/1/0.15, by vol.) and the combined solutions from 20 wells evapotated under nitrogen. TLC was carried out as described for immunostaining. Similar amounts of the different glycolipids were recovered, as judged by eye from the orcinol staining of chromatograms.

\section{Cell culture}

Freshly dissociated cerebellar cells ( $-90 \%$ of which are small cerebellar neurons) from 5- to 7-day-old NMRI mice were plated at a concentration of 3-4 $\times 10^{6}$ cells/ml on poly-L-lysine-coated glass coverslips (Schnitzer and Scthachner, 1981; Keilhaver et al, 1985). For treatment of cells with swainsonine, cerebellar cells were cultured for 2 days in the presence of swainsonine (2 $\mu \mathrm{g} / \mathrm{ml}$, from Sigma) in serum-free, hormone-supplemented medium (Fischer, 1982). The inhibitor was added to the single-cell suspensions prior to plating them on glass coverslips.

\section{Imumunocyrological procedures}

Indirect immunofluorescence staining of monolayer cultures with the monoclonal L3 antibody was carried out according to Fischer et al. (1986) using fluorescein isothiocyanare-conjugated secondary antibodies.

\section{Acknowledgements}

The authors are grateful to Dr Tomoya Ogawa (RIKEN, Wako, Japan) for providing the trisaccharide TS101, Dr A.Haselbeck (Bochringer-Mannheim, FRG) for providing the oligosaccharide Man,GleNAc, A.Marxer for preparing the antigens and antibodies, A.Schwarze for expert technical assistance and Dr R.A.Klein for reading the manuscript.

\section{Abbreviations}

BSA, bovine sorum albumin; ELISA, enzyme-linked immunosorbent assay; ER, endoplasmic reticulum; FAB-MS, fast-atom bombardment mass spectrometry; Gal, galactose; GlcNAc, $N$-acetylglucosamine; Hex, hexose; HexNAcol, $N$-acetylhexosaminitol; HRP, horseradish peroxidase; Man, mannose; PBS, phosphate-buffered saline; TS101, galactose- $\beta 1-4-N$-acetyl-glucasamine-p14-mannose.

\section{References}

Antonicek,H., Persohn,E. and Schactiner,M. (1987) Biochemical and functional characterization of a novel neuron-glia adhesion molecule that is involved in neuronal migration. $J$. Cell BioL, 104, 1587-1595.

Ariga,T., Kohriyama, T., Freddo,L., Latov,N., Saito,M., Kon,K., Ando,S. and Suzuki,M. (1987) Characterization of sulfated ghucuronic acid containing glycolipids reacting with IgM M-proteins in patients with neuropathy. J. Biol. Chem, 262, 848-853.

Arima, T., Spiro,R.G. and Spiro,M.J. (1972) Studies on the carbohydrate units of thyroglobulin. $J$. Biol Chem, 247, 1825-1835.

Asa,D., Gant, T., Oda, Y. and Brandley,B.K. (1992) Evidence for two classes of carbohydrate binding sites on selectins. Ghycobiology, 2, 395-400.

Asada,M., Furulawa, K., Kanitor,C., Gahmberg,C.G. and Kobata, A. (1991) Structural surty of the sugar chains of buman leukocyte cell adhesion molecules CD11/CD18. Biochemistry, 30, 1561-1571.

Bajt,M.L., Schmiz,B., Scturchner,M. and Zipser,B. (1990) Carbohydrate epitopes involved in neural cell recognition are conserved between vertebrate and leech. J. Neurasci. Res., 27, 276-285.

Bazin,H. (1982) Production of rat monoclonal antibodies with Lou rat nonsecreting IR9835 myeloma cells. Prot. Biol. F7uids Proc. Collog., 29, $615-618$.

Blithe,D.L. (1990) N-linked oligosaccharides on free a interfere with its ability to combine with human chorionic gonadotropin- $\beta$ subunit. $J$. Biol. Chem. $265,21951-21956$.

Bollensen,E., Steck,A.J. and Schactiner,M. (1988) Reactivity with the peripheral myelin glycoproteins Po in serum from patients with monoclonal IgM gammopathy and polyncuropathy. Neurology, 38, 1266-1270.

Bronner-Fraser,M. (1987) Perturbation of cranial neural crest migration by the HNK-1 antibody. Dev. Biol, 123, 321-331.

Chow,D.K.H., Myas,A.A., Evans,J.E., Costello,C., Quarles,R.H. and Jungalwala,F.B. (1986) Structure of sulfated glucuronyl glycolipids in the nervous system reacting with HNK-1 antibody and some IgM paraproteins in neuropathy. J. Biol Chem, 261, 11717-11725.

Chou,D.K.H., Prasadara,N., Koul,O. and Jungalwala,F.B. (1991) Developmental expression of HNK-1 reactive antigens in rat cerebral cortex and molecular heterogeneity of sulfoglucuronylneolactotetraosylceramide in CNS versus PNS. J. Newrochem, 57, 852-859.

Egge,H. and Peter-Katalinic,J. (1987) Fast atom bombardment mass spectrometry for structural elucidation of glycoconjugates. Mass Spectrom Rev. , 6, 331-393.

Fahrig,T., Schmitz,B., Weber,D., Kücherer-Ehret,A., Faissner,A. and Sctichner,M. (1990) Two monoclonal antibodies recognizing carbohydrate epitopes on neural adhesion molecules interfere with cell interactions. Eur. J. Neurasci, 2, 153-16I.

Felding-Habermann,B., Jennemann,R., Schmitt,J. and Wiegandt,H. (1986) Glycosphingolipid biosynthesis in early chick embryos. Eur. J. Biachem, 160, 651-658.

Field,M.C., Wing,D.R., Dwek,R.A., Rademacher,T., Schmit,,B., Bollensen,E. and Schachner,M. (1992) Detection of multisulphated N-linked glycans in the L2/HNK-1 carbohydrate epitope expressing neural cell adhesion molecule PO. J. Neurachem, 58, 993-1000.

Fischer,G. (1982) Cultivation of mouse cerebellar cells in serum-free, bormonally defined media: survival of neurons. Neurasci. Lett., 28, 325-329.

Fischer,G., Kilnermund,V. and Schachner,M. (1986) Neurite oungrowh parterns in cerebellar microexplant cultures are affected by antibodies to the cell surface glycoprotein L1. J. Neurasci. 6, 605-612.

Gbarah,A., Gahmberg,C.G., Ofek,I., Jacobi,U. and Sharon,N. (1991) Identification of the leukocyte adhesion molecules CD11/CD18 as receptors for type 1 fimbriated (mannose specific) Escherichia coli. Infect. Immun., 59, 4524-4530.

Gloor,S., Antonicek,H., Sweadner,K.J., Pagliusi,S., Frank,R., Moos,M. and Schachner,M. (1990) The adhesion molecule on glia (AMOG) is : homologue of the beta-subunit of the Na, K-ATPase. J. Cell Biol, 110 , 165-174.

Griffith,S.L.,Schmit,B. and Schachner,M. (1992) The L2/HNK-1 cartohydrate and protein-protein interactions mediate the homophilic binding of the neural cell adhesion molecule P0. J. Neurosci. Res., 33, 639-648.

Hall,H., Liu,L., Schachner,M. and Schmitz,B. (1993) The L2/HNK-1 carbohydrate mediates adhesion of neural cells to laminin. Eur. J. Neurasci., 5, $34-42$.

Hamada, T., Nakajirma, T. and Natsuda,K. (1981) Comparison of the mannan structure from the cell-wall mutant Candida sp. M-7002 and its wild type. Eur. J. Biochem, 119, 373-379.

Horstkorte,R., Schachner,M., Magyar,J.P., Vorther, T. and Schmiz, B. (1993) The fourth immunoglobulin-like domain of NCAM contains a cabohydrate recognition domain for oligomannosidic glycans implicated in association with L1 and neurite outgrowth. J. Cell Biol., 121, 1409-1421.

Hurtley,S.M. and Helenius,A. (1989) Protein oligomerization in the endoplasmatic reticulum. Annu Rev. Cell Biol, 5, 277-307.

Jessell,T.M., Hynes,M.A. and Dodd,J. (1990) Carbohydrates and carbohydrate-binding protein in the nervous system. Annu. Rev. Newrosci., 13 , 227-255.

Keilhauer,G., Faisener,A. and Schachner,M. (1985) Differential inhibition of neurone-neurone, neurone-astrocyte and astrocyte-astrocyte adhesion by L1, L2 and N-CAM antibodies. Nature, 316, 728-730.

Kitamura,K., Suzauki,M. and Uyemura,K. (1976) Purification and partial characterization of two glycoproteins in bovine peripheral nerve myelin membrane. Biochem. Biophys. Acra, 455, 806-816.

Komfeld,R and Kornfeld,S. (1985) Assembly of asparagine-linked oligosaccharides. Annu Rev. Biochem, 54, 631-640.

Kilcherer,A., Faissner,A. and Schechner,M. (1987) The noved carbohydrate epitope L3 is shared by some neural cell adhesion molecules. J. Cell Bial., 104, 1597-1602. 
Künemund,V., Jungalwala,F.B.. Fischer,G., Chou.D.K.H., Keilhauer,G. and Schachner,M. (1988) The L2/HNK-1 carbohydrate of neural cell adhesion molecules is involved in cell interactions. J. Cell Biol., 106, 213-223.

Liang, C.-J., Yamashita,K. and Kobata,A. (1980) Structural study of the carbohydrate moiety of bovine pancreatic ribonuclease B. J. Biochem. 88 , 51-58.

Lis, H. and Sharon,N. (1991) Lectin-carbohydrate interactions. Siruct. Biol, , 1, 741-749.

Loveless, R.W., Floyd-O'Sullivan,G., Raynes,J.G., Yuen,C.-T. and Feizi,T. (1992) Human serum amyloid $P$ is a multispecific adhesive protein whose ligands include 6-phosphorylated mannose and the 3-sulphated sacchandes galactose, $N$-acetylgalactosamine and glucuronic acid EMBO J., 11 , 813-819.

Martini,R. and Schachner,M. (1986) Immunoelectron microscopic localization of neural cell adhesion molecules (L1, N-CAM, and MAG) and their shared carbohydrate epitope and myelin basic protein in developing sciatrc nerve J. Cell Biol. 103, $2439-2448$.

Martini,R., Xin,Y., Schmitz,B. and Schachner,M. (1992) The L2/HNK-1 carbohydrate epitope is involved in the preferential outgrowth of motor neurons on ventral roots and motor nerves. Eur. I Neurasci. 4, 628-639.

Montreuil,J. (1984) Spatial conformations of glycans and glycoproteins. Biol. Cell, 51, 115-132.

Nakajima,H., Itoh,N., Kawasaki,T. and Yamashina,I. (1978) Reaction of antimannan antibodies with oligomannosides and glycopeptides. J. Biochem. 85, $209-216$.

Ofek,I. and Sharon,N. (1988) Lectinophagocytosis: a molecular mechanism of recognition between cell surface sugars and lectins in the phagocytosis of bacteria. Infect. Immun., 56, 539-547.

Parekh,R.B., Tse,A.G.D., Dwek,R.A., Williams,A.F. and Rademacher,T.W. (1987) Tissue-specific $N$-glycosylation, site-specific oligosaccharide patterns and lectin recognition of rat Thy-1. EMBO J., 6, 1233-1244.

Pesheva,P., Horwitz,A.F. and Schachner,M. (1987) Imtegrin, the cell surface receptor for fibronectin and laminin, expresses the $\mathrm{L} 2 / \mathrm{HNK}-1$ and $\mathrm{L} 3$ carbohydrate structures shared by adhesion molecules. Neurosci. Lett., 83, 303-306.

Rathjen,F.G. and Schactuner,M. (1984) Monoclonal antibody LI recognizes neuronal cell surface glycoproteins mediating cellular adhesion. In Behan,P. and Spreafic,F. (eds), Neuroimmunalogy. Raven Press, New York, pp. $79-88$.

Roberts,C., Platt,N., Streit,A., Schochner,M. and Stern,C. (1991) The LS epitope-an early marker for neural induction in the chick embryo and its involvernent in inductive interactions. Development, 112, 959-970.

Schrehner,M. (1989) Families of neural adhesion molecules. In Bock,G. and Harnen,S. (eds), Cabohydrate Recognition in Cellular Function Cibo Foundation Symparium 145, John Wiley \& Sons, Chichester, pp. 56-172.

Schmalzing,G., Kroner,S., Schachner,M. and Gloor,S. (1992) The adhesion molecule on glia (AMOG/B2) and ajphal subunits assemble to functional sodium pumps in Xenopus oocytes. J. Biol. Chem, 267, 20212-20216.

Schneider-Schaulies,J., von Brunn,A. and Schachnet,M. (1990) Recombinant peripheral myelin protein PO confers both adhesion and neurite promoting properties. J. Neurasci Res., 27, 286-297.

Schnitzer,J. and Schachner,M. (1981) Characterization of isolated mouse cerebellar cell populations in vitro. J. Neuroimmunal., 1, 457-470.

Sherblom,A.P., Sathyamoorthy, N., Deckers,J.M. and Muchmore,A.V. (1989) IL-2 a lectin with specificity for high mannose glycopeptides. J. Immunol., 143, 939-944.

Stoll,M.S., Mizuochi,T., Childs,R.A. and Feizi, T. (1988) Improved procedure for the construction of neoglycolipids having antigeric and lectin-binding activities, from reducing oligosaccharides. Biochemistry, 256, 661-664.

Streit,A., Faissner,A., Gehrig,B. and Schachner,M. (1990) Isolation and biochemical characterization of a neural proteoglycan expressing the LS carbohydrate epitope. J. Neurochem. 55, 1494-1506.

Streit,A., Nolte,C., Rasony, T. and Schachner,M. (1993) Interaction of astrochondrin with extracellular matrix components and its involvement in astrocyte process formation and cerebellar granule cell migration. J. Cell Biol. 120, 799-814.

Tai,T., Yamashita,K. and Kobats,A. (1977) The substrate specificities of endo- $\beta-N$-acetylglucosaminidases $\mathrm{C}$ and $\mathrm{H}$. Biachem Biophys. Res. Commin, 78, 434-441.

Takasali,S., Mizuocti, T. and Kobata,A. (1982) Hydrazinolysis of asparaginelinked sugar chains to produce free oligosaccharides. Methods Encymol., 83, 263-268.

Tang,P.W., Goot,H.C., Handy,M., Lee,Y.C. and Feizi,T. (1985) Novel approach to the study of the antigenicities and receptor functions of carbohydrate chains of glycoproteins. Biochem. Biophys. Res. Commun, 132, $474-480$.
Tarentino,A.L., Trimble,R.B. and Maley,F. (1978) endo- $\beta-N$-Acerylglucosaminidase from Streptomyces plicarus. Methods Enzymol., S0, 574-579.

Taylor,M.E., Bezouska,K. and Drickamer,K. (1992) Contribution to ligand binding by multiple carbohydrate-recognition domains in the macrophage mannose receptor. J. Biol. Chem, 267, 1719-1726.

Tulsiani,D.R.P., Coleman,V.D. and Touster,O. (1990) Asparagine-linked glycoprotein biosynthesis in rat brain: identification of glucosidase I, glucosidase II, and an endomannosidase (glucosyl mannosidase). Arch. Biochem Biophys, 277, 114-121.

Uyemura,K. and Kitamura,K. (1991) Comparative studies of myelin proteins in mammalian peripheral nerve. Comp. Biochem. Physiol., 98C, 63-72.

Received on June 28. 1993; revised on September 8, 1993; accepted on September 9, 1993 